\title{
Effect of physical stresses on survivability and post-exposure antibiotic susceptibility of coliforms in environmental waters and wastewaters
}

\author{
*Adebisi, O. O., Gbala, I. D., Akinsolu, F. T., and Olayemi, A. B. \\ Section of Integrative Bioenergetics Environmental and Ecotoxicological Systems, Department of Microbiology, \\ Faculty of Life Sciences, University of Ilorin, P.M.B. 1515, Ilorin, Nigeria \\ *Correspondence to: oo.adebisi@outlook.com; soji-olusegun@unilorin.edu.ng
}

\begin{abstract}
:
Background: Coliform bacteria are majorly introduced into water bodies (river and wastewater) as a result of faecal pollution, agricultural run-offs and several anthropogenic activities. Despite the effectiveness of water treatment methods, pathogens still persist in water; hence the relevance of assessing the ability of these pathogens to survive the lethal actions of physical stresses and the possible impact on antibiotic susceptibility pattern of the organisms.

Methodology: The survivability of Escherichia coli strains (NCM3722, FAP1 and ST2747), Enterobacter cloacae GGT036 and Shigella sonnei 53G was assessed in environmental and waste waters for 21 days. The effect of three treatment regimens (UV radiation, solar radiation and boiling) on the survival of the coliforms was evaluated. Also, the antibiogram of the isolates post-UV exposure was assayed.

Results: Although there was significant reduction $(\geq 3-\mathrm{log})$ in the population of the bacteria overtime, all the coliforms survived in the waters for 21 days. The effect of UV radiation was significant on all organisms (> 3 log reductions). Solar radiation for 60 minutes had significantly lesser effect than boiling for 15 minutes. Surviving cells of all isolates demonstrated multiple drug-resistance post exposure to UV radiation. Conclusion: This study revealed the ability of coliforms to persist in waters after treatment and proves that UV radiation may not be effective in attenuation of antibiotic resistance.
\end{abstract}

Keywords: Survivability; Coliforms; Antibiotic susceptibility; Water; Wastewater

Received December 17, 2018; Revised June 2, 2019; Accepted June 3, 2019

Copyright 2019 AJCEM Open Access. This article is licensed and distributed under the terms of the Creative Commons Attrition 4.0 International License (http://creativecommmons.org/licenses/by/4.0), which permits unrestricted use, distribution and reproduction in any medium, provided credit is given to the original author(s) and the source.

\section{Effet des contraintes physiques sur la capacité de survie et la susceptibilité aux antibiotiques post-exposition aux coliformes dans les eaux de surface et les eaux usées}

\author{
*Adebisi, O. O., Gbala, I. D., Akinsolu, F. T., et Olayemi, A. B
}

Section de la bioénergétique intégrative Systèmes environnementaux et écotoxicologiques, Département de microbiologie, Faculté des sciences de la vie, Université d'Ilorin, P.M.B. 1515, Ilorin, Nigeria

*Correspondance à: oo.adebisi@outlook.com; soji-olusegun@unilorin.edu.ng

\section{Abstrait:}

Contexte: Les bactéries coliformes sont principalement introduites dans les eaux (rivières et eaux usées) en raison de la pollution fécale, des écoulements agricoles et de plusieurs activités anthropiques. Malgré l'efficacité des méthodes de traitement de l'eau, les agents pathogènes persistent dans l'eau; D'où la pertinence d'évaluer la capacité de ces agents pathogènes à survivre aux actions létales des stress physiques et à l'impact possible sur le profil de sensibilité des organismes aux antibiotiques.

Méthodologie: La capacité de survie des souches d'Escherichia coli (NCM3722, FAP1 et ST2747), de Enterobacter cloacae GGT036 et de Shigella sonnei 53G a été évaluée pendant 21 jours dans des eaux environnementales et des eaux usées. L'effet de trois schémas thérapeutiques (rayonnement UV, rayonnement solaire et ébullition) sur la survie des coliformes a été évalué. En outre, l'antibiogramme des isolats après l'exposition aux UV a été testé.

Résultats: Bien qu'il y ait eu une réduction significative ( $\geq 3 \mathrm{log}$ ) de la population de bactéries en heures supplémentaires, tous les coliformes ont survécu dans les eaux pendant 21 jours. L'effet du rayonnement UV était significatif sur tous les organismes (réductions de> $3 \mathrm{log}$ ). Le rayonnement solaire pendant 60 minutes a 
eu un effet significativement moindre que celui d'ébullition pendant 15 minutes. Les cellules survivantes de tous les isolats ont démontré une résistance multiple aux médicaments après une exposition aux rayons UV. Conclusion: cette étude a révélé la capacité des coliformes à persister dans les eaux après traitement et prouve que le rayonnement UV peut ne pas atténuer efficacement la résistance aux antibiotiques.

Mots-clés: Survivabilité; Les coliformes; Sensibilité aux antibiotiques; Eau; Eaux usées

\section{Introduction:}

Coliforms serve as the conciliation between the demand for safe water and the tedious process of isolation and culture of pathogens in water. Positive results of coliforms in water samples usually suggest the presence of disease-causing pathogens which may be life threatening. Basically, coliforms are unlikely to cause diseases but there are exceptions with some strains at specific physiological conditions. Escherichia coli, Enterobacter sp., Shigella sp., Salmonella sp. and Enterococci sp. are commonly isolated coliform bacteria in environmental waters and their occurrence or survival are dependent on various physiological processes (1).

Escherichia coli NCM3722 is a wildtype prototrophic strain that is capable of optimal growth in minimal medium- it can survive on inorganic salts only with simple energy sources such as sugar and water (2). This strain exhibits unique physiological properties including galactose metabolism. Escherichia coli FAP1 is a strain that has been reported to harbour the CTX-M ESBL gene that codes for resistance against cephalosporins (3). Escherichia coli ST2747 is a pathogenic intestinal strain unique for its virulence in intestinal infections (4). Enterobacter cloacae GGT036 is a furfuraltolerant strain with ability to persist in the environment for a long period (5). Enterobacter species are pathogens that can cause fatal infections especially in hospital settings. Shigella sonnei $53 \mathrm{G}$ is a pathogenic strain that carries plasmid-encoded resistance genes and also a potential aetiology of bacillary dysentery (6).

Coliform bacteria are majorly introduced into water bodies (river and wastewater) as a result of faecal pollution, agricultural run-offs and several anthropogenic activities. Presence of pathogens in rivers and wastewater could serve as a channel for community-acquired infections through consumption or use in agricultural or domestic purposes. There are a couple of primary methods in use for reducing pathogens and coliforms in water to an acceptable standard for potability.

Water decontamination procedures include boiling, filtration, ultraviolet, solar and chemical disinfection (7). Boiling water to a 'rolling-boil' level for 1 minute at temperature of $212^{\circ} \mathrm{F}$ or $100^{\circ} \mathrm{C}$ has been reported to inactivate bacteria, viruses, protozoa and other waterborne pathogens (8). The heat involved in boiling damages the structural composition of organisms thereby interfering with basic metabolic processes required for survival. Some studies have reported that Shigella, Salmonella, E. coli (ETEC) and Vibrio cholerae can be inactivated by boiling water at $65^{\circ} \mathrm{C}$ for 20 minutes (9). However, the effectiveness of boiling on the varying waterborne pathogens is dependent on temperature and time.

Solar disinfection involves the use of energy from sunlight for pathogen reduction in water and wastewater. The effect of this low-cost technique on pathogens has been reported to be detrimental through denaturation of cells resulting in death. The effectiveness of solar radiation in waterborne pathogen elimination however depends on the intensity of the sunlight, atmospheric temperature, water depth, turbidity of the water as well as duration of exposure (10, 11). Ultra violet (UV) rays form part of the natural sunlight but they have a higher spectrum frequency than visible light and lower than x-ray. UV light is effective against bacteria, viruses and also Giardia lamblia cysts and Cryptosporidium oocysts. The extent of effectiveness of UV disinfection however depends on the dose/power of the light, delivery of the light, time of exposure and the turbidity of the water $(7,12)$. Despite the effectiveness of these water treatment methods, pathogens still persist in some water samples, hence the relevance of assessing the ability of these pathogens to survive the lethal actions of physical stresses and the possible impact on antibiotic susceptibility pattern of the organisms. In this research, the survivability of E. coli ST2747, E. coli NCM3722 E. coli FAP1, Enterobacter cloacae strain GGT036 and Shigella sonnei $53 \mathrm{G}$ after exposures to boiling, solar disinfection and ultraviolet treatment was assessed. The research also evaluated the effect of these treatment methods on the antibiotic susceptibility of the organisms.

\section{Materials and Methods:}

\section{Collection and analysis of water and wastewater samples}

The river water was collected from Oyun River dam at the University of Ilorin 
main campus and borehole water from private borehole located at Jalala village, Ilorin, Nigeria. Agricultural wastewater was collected from a fish farm at Oke-Odo community, Ilorin while domestic wastewater was composited from samples collected from outlets of kitchen and bathroom of a flat at a private estate in Tanke, Ilorin. Temperature and $\mathrm{pH}$ of samples were measured at the site of collection using a mercury-in-glass thermometer and hand-held $\mathrm{pH}$ meter. Turbidity of water and wastewater samples was determined using a spectrophotometer measured at $460 \mathrm{~nm}$ wavelength.

\section{Preparation of pure bacterial cell suspension} The isolates (Escherichia coli NCM3722, Escherichia coli FAP1, Escherichia coli ST2747, Enterobacter cloacae GGT036 and Shigella sonnei 53G) used in this study were previously recovered from river water, characterised and identified using 16S rRNA sequencing. The antibiogram profiles of the isolates have also been previously determined and they were kept in the laboratory of Department of Microbiology, University of Ilorin. The isolates were resuscitated from their stocks on CLED agar (CM-CLED096, pH 7.5; Rapid Lab, UK). The purity of the culture was validated by repeated sub-culturing.

To obtain large cell culture at exponential growth phase for the survival experiment, the isolates were first grown in nutrient broth in a shaker incubator $\left(37^{\circ} \mathrm{C}\right.$, $100 \mathrm{rpm}$ ) for 48-72 hours. The cell pellets were harvested by centrifugation at 3500 rpm for 10 minutes (Axiom Medical). After each run of centrifugation, the supernatant was carefully decanted and cell pellets resuspended in a phosphate buffer solution (PBS). The process was repeated several times until pure cell pellets were obtained. Finally, the cells were suspended in PBS and kept in the refrigerator at about $4^{\circ} \mathrm{C}$ until use but not for more than four days.

\section{Inoculum standardization}

McFarland standards (barium chloride and sulphuric acid) were used to standardize the inoculum to a cell concentration in the range of $10^{6}$ to $10^{8}$ cells as most frequently found in polluted water and wastewater in nature. Using the spectrophotometer $(600 \mathrm{~nm})$, the absorbance of the cell suspension was adjusted by dilution with sterile distilled water to achieve bacteria number of approximately $1-2 \times 10^{8} \mathrm{CFU} / \mathrm{ml}$ (13).

\section{Survival experiment}

Prior to the experiment, the water and wastewater samples were sterilised by repeated autoclaving at $121^{\circ} \mathrm{C}$ for 15 minutes for three consecutive times for three alternating days (14). This was to ensure that all microbial spores were totally destroyed and bacterial re-growth is prevented. The effectiveness of this sterilisation technique was initially verified by plating out $1 \mathrm{ml}$ of the sterilized wastewater on nutrient agar and potato dextrose agar and incubating at $37^{\circ} \mathrm{C}$ for 24 hours and $25^{\circ} \mathrm{C}$ for $7-10$ days, respectively. Previous studies have shown that this process does not have significant effect on the properties of the environmental media $(14,15,16)$. Aliquots $(1 \mathrm{ml})$ of cell suspensions were added to $99 \mathrm{ml}$ of sterilised water or wastewater in $250 \mathrm{ml}$ capacity glass flasks to give a final cell concentration of approximately $1.2 \times 10^{6} \mathrm{CFU} / \mathrm{ml}$.

Static state incubation of the seeded environmental media was performed at room temperature $\left(25 \pm 2^{\circ} \mathrm{C}\right)$ and sampling was carried out on days $0,3,6,9,12,15,18$ and 21 for assessment of bacteria survival. At the times of sampling, the flasks were gently swirled for about 1 minute to dislodge any biofilm or settled microbial mass on the walls and surfaces of the flasks. Sub-samples were aseptically withdrawn from the flasks and appropriate serial dilutions made. From the last three diluents, $0.5 \mathrm{ml}$ aliquots were taken and inoculated on appropriate culture agar media. MacConkey agar was used to culture the three strains of E. coli, Shigella sonnei 53G was cultured on Salmonella Shigella Agar (SSA) while Enterobacter cloacae GGT036 was cultured on Cysteine Lactose Electrolyte Deficient (CLED) agar $(15,16)$.

Disinfection treatment of water and
wastewater
Before introducing the standardized inocula of isolates $\left(1.2 \times 10^{6} \mathrm{CFU} / \mathrm{ml}\right)$, the water and wastewater were first sterilized following the procedure described earlier. The seeded water and waste water $(100 \mathrm{ml}$ in $250 \mathrm{ml}$ capacity glass flasks) were treated to assess the effectiveness of selected treatment/disinfection techniques for the water and wastewater. Three different treatment regimens were studied: (1) Solar disinfection was carried out by exposing to sunlight (at $38 \pm 2^{\circ} \mathrm{C}$ ) for 60 minutes with the flasks placed on a height of $120 \mathrm{~m}$ above ground level and without any structure obstructing; (2) Moist heat disinfection was performed by heating the flasks placed in a water bath to $100^{\circ} \mathrm{C}$ for 15 minutes; (3) Ultraviolet disinfection was done by exposing the water and wastewater $(20 \mathrm{ml})$ in $90 \mathrm{~mm}$ glass Petri dishes placed at approximately 50 $\mathrm{cm}$ to a UV light source for 15 and 30 minutes. After exposure, an aliquot $(1 \mathrm{ml})$ of each treated sample was plated on appropriate culture media using the pour- 
plate technique. The plates were incubated at $37^{\circ} \mathrm{C}$ for Enterobacter cloacae GGT036 and Shigella sonnei $53 \mathrm{G}$ and at $45^{\circ} \mathrm{C}$ for the strains of Escherichia coli. Enumeration was done after 48 hours of incubation. While a single flask/Petri dish was used for each treatment set-up, the inoculation on culture plates was done in replicates $(15,16)$.

\section{Antibiotic susceptibility testing}

The surviving cells of the isolates after exposure to UV radiation for 30 minutes were tested against eight antibiotics in five different classes (penicillins, cephalosporins, nitrofurans, fluoroquinolones and aminoglycosides) using the Kirby-Bauer disk diffusion method (13). Prior to susceptibility assay, the cells were re-cultured into a sterile nutrient broth (48 hours inoculation in a shaker incubator at $37^{\circ} \mathrm{C}$ and $100 \mathrm{rpm}$ ) to obtain enough cell mass up to a concentration of $1-2 \times 10^{8} \quad \mathrm{CFU} / \mathrm{ml}$. Mueller Hinton agar was inoculated with the test isolates (obtained from the various treated water and wastewater samples after exposure). Thereafter, the following eight antibiotic disks were placed on the agar surface; ceftazidime $(30 \mu \mathrm{g})$, cefuroxime $(30 \mu \mathrm{g})$, gentamicin $(10 \mu \mathrm{g})$, ciprofloxacin $(5 \mu \mathrm{g})$, ofloxacin $(5 \mu \mathrm{g})$, amoxicillin/clavulanate $(30 \mu \mathrm{g})$, nitrofurantoin $(300 \mu \mathrm{g})$, and ampicillin $(10 \mu \mathrm{g})$. The plates were incubated for $16-24$ hours at $37^{\circ} \mathrm{C}$. To evaluate possible effect of prolonged exposure, the plates were further incubated for 72 hours, following which the diameter of zone of inhibition around each antibiotic disk was measured with a ruler.

\section{Results:}

Physicochemical characteristics of the environmental waters and wastewaters

Results presented in Table 1 show that physicochemical parameters of the borehole and river water samples were not different. However, the domestic and agricultural (fishery) wastewaters differed in their $\mathrm{pH}$ and turbidity. The domestic wastewater had the highest turbidity and lowest $\mathrm{pH}$.

Table 1: Physicochemical properties of water and wastewater samples

\begin{tabular}{|c|c|c|c|c|c|}
\hline Type & Sample & Colour/appearance & $\begin{array}{c}\text { Temp. } \\
\left({ }^{\circ} \mathrm{C}\right)\end{array}$ & $\mathrm{pH}$ & $\begin{array}{c}\text { Turbidity } \\
(\AA)\end{array}$ \\
\hline \multirow[t]{2}{*}{ Wastewater } & Fishery & Greenish, with lots of suspended particles & 31 & 9.7 & 0.455 \\
\hline & Domestic & Cloudy, with suspended particles & 32 & 5.0 & 1.737 \\
\hline \multirow[t]{2}{*}{ Water } & Borehole & Colourless and clear & 32 & 8.7 & 0.014 \\
\hline & River & Colourless, with few suspended particles & 32 & 8.9 & 0.016 \\
\hline
\end{tabular}
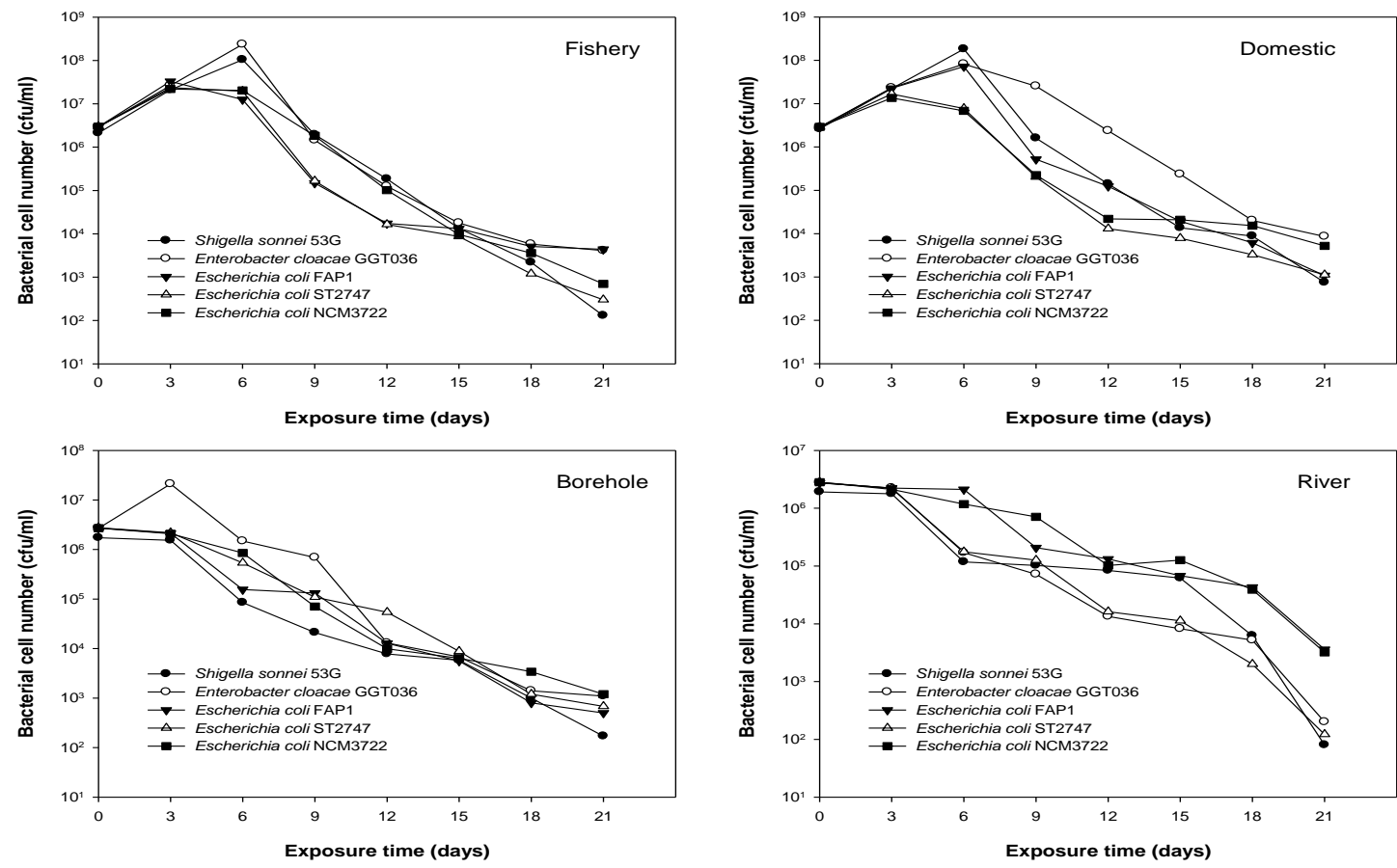

Fig 1: Survival of Shigella sonnei $53 \mathrm{G}(\bullet)$, Enterobacter cloacae GGT036 (0), Escherichia coli FAP1 ( $\nabla$ ), Escherichia coli ST2747 (A) and Escherichia coli NCM3722 ( $(\boldsymbol{\omega})$ in environmental waters and wastewaters 
Survivability of pathogens in environmental waters and wastewaters

Survivability of the bacteria in different environmental waters and wastewaters are presented in Figure 1 . All the five bacteria demonstrated similar survival trends in the wastewaters, with an appreciable increase in cell populations in the first 6 days before a gradual decline thereafter. The decline became significant after 18 days of incubation for all organisms in fishery wastewater (>3 log reduction from $1.2 \times 10^{6}$ to $1.2-5.8 \times 10^{3} \mathrm{CFU} / \mathrm{ml}$ ) (Fig. $1 \mathrm{a}$ ) and for Shigella sonnei 53G, E. coli strains FAP1 and ST2747 in domestic wastewater (>3 log reduction from $1.2 \times 10^{6}$ to $3.3-8.8 \times 10^{3}$ CFU/ml) (Fig. 1b). While Shigella sonnei $53 \mathrm{G}$ appeared to propagate better in the initial days, it did not survive as much as the $E$. coli strains in the latter days in the wastewaters. There was no difference in the pattern of growth or extent of survival of the three strains of $E$. coli investigated. Enterobacter cloacae GGT036 survived better than both Shigella sonnei 53G and E. coli ST2747 in the wastewaters (Fig. 1a-b).

Unlike the wastewaters, neither borehole nor river water seemed to support the proliferation of bacteria nonetheless the organisms survived for over 21 days in them (Fig. 1a-d). There were differences in the pattern and extent of bacteria survival in the borehole and river water (Fig. 1c-d). Enterobacter cloacae GGT036, E. coli strains ST2747 and NCM3722 maintained their populations for the first 6 days while Shigella sonnei $53 \mathrm{G}$ and $E$. coli FAP1 numbers declined after 3 days in borehole water (Fig. $1 c)$. In the river water, the population of $E$. coli FAP1 was maintained up to 6 days but that of Enterobacter cloacae GGT036 or $E$. coli ST2747 reduced after 3 days, unlike what was observed in the borehole water
(Fig. 1d). In the borehole water, decline in population of all bacterial species was significant after 15 days of incubation ( $>3$ $\log$ reduction from $1.2 \times 10^{6}$ to $5.6-8.8 \times$ $10^{3} \mathrm{CFU} / \mathrm{ml}$ ) (Fig. 1c). In river water, the decline in bacterial populations became significant for Shigella sonnei 53G, Enterobacter cloacae GGT036 and E. coli ST2747 after 18 days ( $>3$ log reduction from $1.2 \times 10^{6}$ to $2.0-6.2 \times 10^{3} \mathrm{CFU} / \mathrm{ml}$ ) and for E. coli strains FAP1 and NCM3722 only by 21 days of incubation ( $>3$ log reduction from 1.2 $\times 10^{6}$ to $3.2-3.6 \times 10^{3} \mathrm{CFU} / \mathrm{ml}$ ) (Fig. $1 \mathrm{~d}$ ).

Effects of treatment regimens on survivability of isolates in environmental and wastewaters Results of the effect of UV radiation on bacterial survival in environmental waters and wastewaters are shown in Table 2. The effect of UV radiation was significant on all organisms ( $>3 \mathrm{log}$ reductions in cell numbers); this being greater at longer exposure duration. Although not statistically significant, there were greater reductions in cell numbers of Shigella sonnei 53G than for Enterobacter cloacae GGT036 at the two exposure times and for the three strains of $E$. coli after 30 minutes of exposure, in all waters and wastewater investigated (Table $2)$. Solar radiation for 60 minutes had significantly less effect than wet heat treatment for 15 minutes on bacterial survival (Table 3 ). While solar radiation for 60 minutes achieved only 2-3 log reductions in cell numbers, boiling for 15 minutes resulted in $>4$ log reductions in cell numbers or caused completed elimination of the organisms, particularly in the environmental waters (Table 3). In comparison, UV radiation for at least 30 minutes was nearly as effective as boiling for 15 minutes at drastically reducing $(P<0.05)$ the pathogen populations in the wastewaters.

Table 2: Effed of ultraviolet radiation on bacterial survival in environmental waters and wastewaters

\begin{tabular}{|c|c|c|c|c|c|c|c|c|}
\hline \multirow{4}{*}{ Baderia' } & \multicolumn{8}{|c|}{ Baderial Counts $(\mathrm{cfu} / \mathrm{ml})$} \\
\hline & \multicolumn{2}{|c|}{ Fishery } & \multicolumn{2}{|c|}{ Domestic } & \multicolumn{2}{|c|}{ Borehole } & \multicolumn{2}{|c|}{ River } \\
\hline & \multicolumn{8}{|c|}{ Exposure Duration (minutes) } \\
\hline & 15 & 30 & 15 & 30 & 15 & 30 & 15 & 30 \\
\hline Shigella sonnei $53 \mathrm{G}$ & $2,94 \times 10^{3}$ & $1.62 \times 10^{1}$ & $5.40 \times 10^{2}$ & $4.00 \times 10^{1}$ & $1.00 \times 10^{2}$ & 8.00 & $2.00 \times 10^{2}$ & $1.30 \times 10^{1}$ \\
\hline Enterobacter closcse GGT036 & $2.17 \times 10^{3}$ & $1.26 \times 10^{2}$ & $2.29 \times 10^{3}$ & $9.20 \times 10^{1}$ & $2.10 \times 10^{3}$ & $1.80 \times 10^{1}$ & $9.80 \times 10^{2}$ & $8.80 \times 10^{1}$ \\
\hline Escherichia coli FAP1 & $8,60 \times 10^{2}$ & $7.20 \times 10^{1}$ & $5.20 \times 10^{2}$ & $6.30 \times 10^{1}$ & $9.00 \times 10^{2}$ & $2,90 \times 10^{1}$ & $2.60 \times 10^{2}$ & $5.80 \times 10^{1}$ \\
\hline Escherichia woli ST2747 & $1.18 \times 10^{2}$ & $1.02 \times 10^{1}$ & $6.80 \times 10^{2}$ & $5.80 \times 10^{1}$ & $2.80 \times 10^{2}$ & $640 \times 10^{1}$ & $3.40 \times 10^{3}$ & $9,90 \times 10^{1}$ \\
\hline Escherichia coli NCM 3722 & $6.80 \times 10^{3}$ & $6.40 \times 10^{1}$ & $9.50 \times 10^{2}$ & $5.80 \times 10^{1}$ & $5.40 \times 10^{2}$ & $4.80 \times 10^{1}$ & $2.80 \times 10^{3}$ & $2.40 \times 10^{1}$ \\
\hline
\end{tabular}

'Initial inooulum size was estimated by McFarland standard to approximately $1.2 \times 10^{6} \mathrm{CFU} / \mathrm{ml}$ 
Table 3: Effed of sunlight heat and boiling on bacterial survival in environmental waters and wastewaters

\begin{tabular}{|c|c|c|c|c|c|c|c|c|}
\hline \multirow{3}{*}{ Baderia' } & \multicolumn{8}{|c|}{ Baderial Counts (CFU/ml) } \\
\hline & \multicolumn{2}{|c|}{ Fishery } & \multicolumn{2}{|c|}{ Domestic } & \multicolumn{2}{|c|}{ Borehole } & \multicolumn{2}{|c|}{ River } \\
\hline & $\begin{array}{l}\text { Sunlight } \\
\text { (60 mins) }\end{array}$ & $\begin{array}{c}\text { Boiling } \\
\text { (15 mins) }\end{array}$ & $\begin{array}{l}\text { Sunlight } \\
\text { (60 mins) }\end{array}$ & $\begin{array}{c}\text { Boiling } \\
\text { (15 mins) }\end{array}$ & $\begin{array}{l}\text { Sunlight } \\
\text { (60 mins) }\end{array}$ & $\begin{array}{c}\text { Boiling } \\
\text { (15 mins) }\end{array}$ & $\begin{array}{l}\text { Sunlight } \\
\text { (60 mins) }\end{array}$ & $\begin{array}{c}\text { Boiling } \\
\text { (15 mins) }\end{array}$ \\
\hline Shigellas sonnei $53 \mathrm{G}$ & $2.20 \times 10^{3}$ & $1,32 \times 10^{1}$ & $1.82 \times 10^{\circ}$ & $1.28 \times 10^{2}$ & $1.57 \times 10^{3}$ & $<1$ & $1.73 \times 10^{3}$ & 4 \\
\hline Enterobacter doaca GGTO36 & $1.70 \times 10^{\circ}$ & $1.54 \times 10^{2}$ & $1.24 \times 10^{4}$ & $9.40 \times 10^{1}$ & $1.82 \times 10^{3}$ & $3.20 \times 10^{1}$ & $1.87 \times 10^{3}$ & $1,00 \times 10^{1}$ \\
\hline Escherichia coli FAP1 & $2.53 \times 10^{\circ}$ & $1,90 \times 10^{1}$ & $2.46 \times 10^{3}$ & $2.20 \times 10^{1}$ & $1.99 \times 10^{4}$ & $<1$ & $2.26 \times 10^{0}$ & $<1$ \\
\hline Escherichia coli ST2747 & $2.37 \times 10^{3}$ & $1,38 \times 10^{2}$ & $1.86 \times 10^{3}$ & $1.20 \times 10^{1}$ & $1.65 \times 10^{3}$ & $<1$ & $1.48 \times 10^{3}$ & $1,30 \times 10^{1}$ \\
\hline Escherichia codi NOM3722 & $2.14 \times 10^{3}$ & $2.02 \times 10^{1}$ & $2,68 \times 10^{3}$ & $2,60 \times 10^{1}$ & $2.08 \times 10^{2}$ & 2.00 & $1.97 \times 10^{3}$ & $<1$ \\
\hline
\end{tabular}

' Initial inoulum size was estimated by Mofarland standard to approximately $1.2 \times 10^{6} \mathrm{CFU} / \mathrm{ml}$

Antibiotic susceptibility of test isolates after exposure to UV radiation for $\mathbf{3 0}$ minutes Antibiotic susceptibility profiles of the five bacteria recovered from the various environmental waters and wastewaters after exposure to UV radiation for 30 minutes are presented in Figure 2. In general, the effect of UV radiation on antibiotic sensitivity of the organisms varied depending on the environmental waters or wastewaters. However, all the isolates exhibited multi-drug resistance with resistance to at least six of the eight antibiotics used. In the fishery wastewater, all the isolates recovered showed resistance to the antibiotics except Escherichia coli ST2747 and Enterobacter cloacae GGT036 which both showed intermediate susceptibility to ofloxacin and ciprofloxacin (Fig 2a).

$$
\text { From domestic wastewater, }
$$
Enterobacter cloacae GGT036, Escherichia coli NCM3722 and Shigella sonnei 53G exhibited intermediate susceptibility to ofloxacin, ciprofloxacin and gentamicin (Fig 2b). In borehole water, all the isolates recovered showed intermediate susceptibility to ciprofloxacin and ofloxacin except Enterobacter cloacae GGT036 which was resistant to the latter; while Escherichia coli FAP1 alone showed intermediate susceptibility to gentamicin (Fig 2c). Among the isolates recovered from the river water, Escherichia coli FAP1 and Enterobacter cloacae GGT036 were both sensitive to ofloxacin while Shigella sonnei 53G showed intermediate susceptibility to it. Escherichia coli ST2747, Enterobacter cloacae GGT036 and Shigella sonnei 53G were intermediately susceptible to ciprofloxacin while other isolates were resistant (Fig 2d). Ofloxacin, gentamicin and ciprofloxacin displayed better efficacy against the isolates compared to other antibiotics.

\section{Discussion:}

The temperature of the environmental waters and wastewaters used in this study were within the optimum temperature range for the survival of most mesophiles but the temperature recorded for borehole water is higher than the permissible standard of $25^{\circ} \mathrm{C}(14)$. Generally, the temperature range of the waters recorded in this study is higher than previous studies where temperature ranges within $25 \pm 2^{\circ} \mathrm{C}$ were reported $(17,18$, 19). The variation in the temperatures may be due to seasonal and geographical influence on the samples collected. The $\mathrm{pH}$ values of the water and wastewater samples varied from slightly acidic to slightly alkaline (5.0-9.7) which are however slightly higher than the recommended range for wastewaters (6.5-9.0) and surface/ground waters (6.0-8.0). The acidic $\mathrm{pH}$ and high turbidity observed in the domestic wastewater could be influenced by the nature of the organic and inorganic contents such as sewage, detergents and toxic elements (19). Fish wastes and fish feeds contain carbonate salts that can make water more basic, hence the fairly higher alkalinity observed in fishery wastewater compared to the environmental waters. Comparatively, the turbidity of the wastewaters was higher than environmental waters which may be due to the presence and high amounts of suspended and dissolved solids.

All the coliforms persisted in the river and borehole waters for over 21 days with an estimated 4-log and 5-log reduction respectively in the bacterial counts over an exposure time of 21 days. The survivorship of the coliforms in these environmental waters despite the low content of suspended solids or organic matter may be due to their capability to grow optimally in minimal 

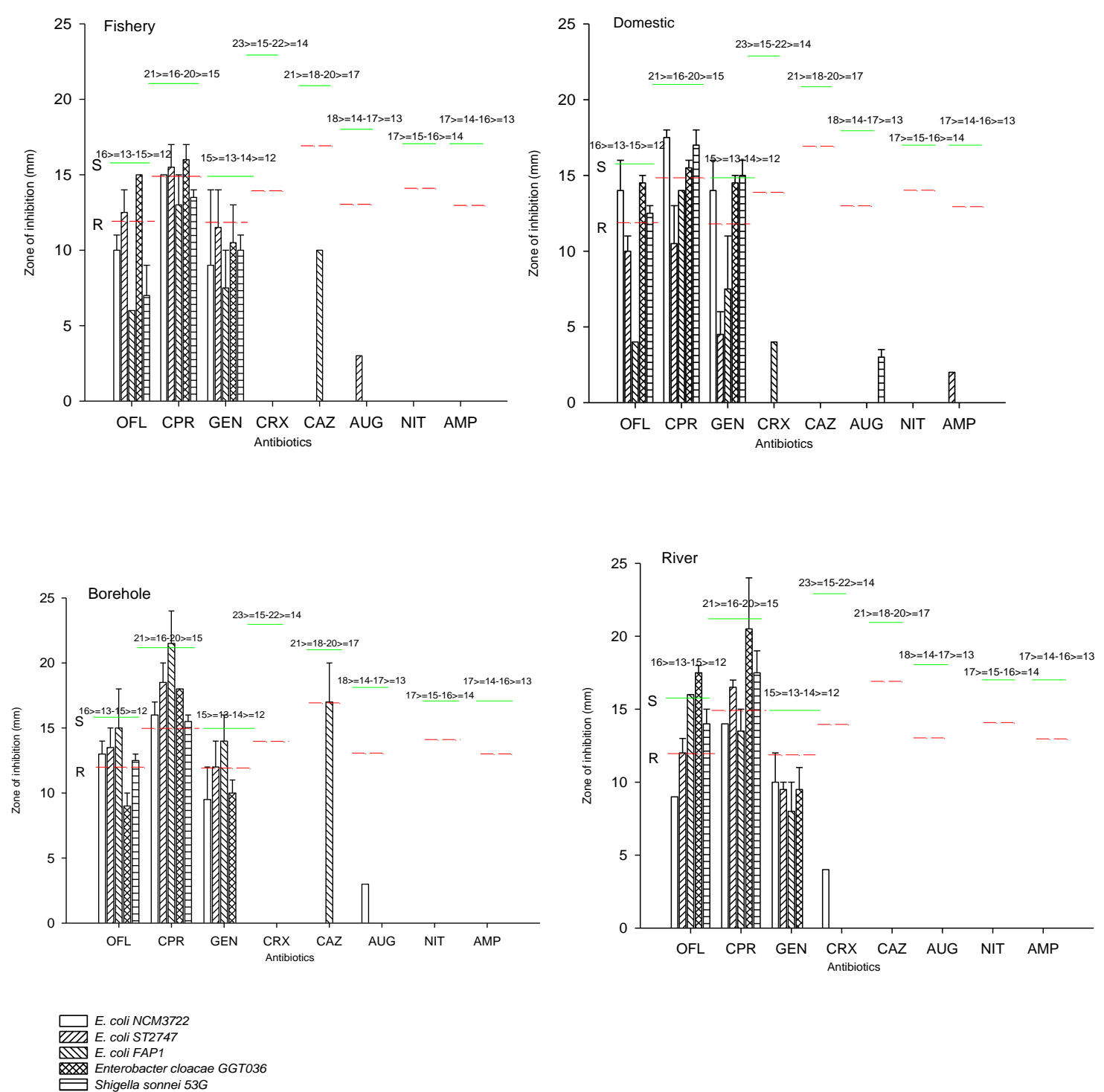

Fig 2: Susceptibility of the isolates from the waters to antibiotics after UV radiation exposure $S$ represents 'sensitive'; R represents 'resistant'

medium and utilize simple energy sources (2). The survival pattern of all the bacterial isolates in the wastewaters was similar with a significant decline in bacterial counts from days 6 to 12; while fluctuations in growth were observed in the environmental waters until bacterial counts significantly declined from days 15 to 21 .

In all the water samples, Escherichia coli strains showed higher survivability compared to Shigella sonnei and Enterobacter cloacae; thus reiterating the capability of these strains to switch to a state of dormancy and persist in the environment for a long period of time $(20,21)$. The survival rate of these coliforms in these waters especially borehole water is intriguing and this may present a health risk in the discharge, use and consumption of these waters.

Ultraviolet radiation has gained widespread use as a means of inactivating microorganisms in water bodies. Its general acceptance has been favoured by its efficacy at low contact time, no formation of harmful by-products and no chemical involvement $(22,23,24)$. In this study, all bacterial counts decreased with increase in contact time to UV radiation with at least 4-log reduction. In fishery wastewater, over 2-log reduction was observed in the bacterial counts from exposure for 15 to 30 minutes. A similar trend was observed in the domestic wastewater with bacterial counts after 30 minutes being almost negligible. In borehole water, bacterial counts declined drastically to 
$<65 \mathrm{cfu} / \mathrm{ml}$ after 30 minutes while in river water, bacterial counts were less than 100 $\mathrm{cfu} / \mathrm{ml}$ after 30 minutes of UV exposure. Shigella sonnei $53 \mathrm{G}$ showed a notable inactivation rate to UV disinfection with $<20$ $\mathrm{cfu} / \mathrm{ml}$ in all the water samples after 30 minutes of UV exposure.

Solar irradiation has been used extensively in disinfection of chemically and biologically contaminated water. Bacteria inactivation by solar disinfection in the wastewaters and environmental waters was significantly different. The coliforms survived better in the wastewaters after 60 minutes of sunlight exposure compared to the environmental waters. This observation could be attributed to the effect of turbidity on light penetration into the water samples. Bacterial inactivation by solar irradiation has been studied to be proportional to the intensity of sunlight while presence of suspended solids in water reduces the intensity of light (9). Boiling water at $100^{\circ} \mathrm{C}$ can reportedly inactivate a wide range of microorganisms. Similar to the survivability rate to solar irradiation, the coliforms survived better in the wastewaters than the environmental waters after 15 minutes of boiling. In borehole and river waters, bacterial counts were less than $1 \mathrm{cfu} / \mathrm{ml}$ for three of the coliforms in each of the waters. Enterobacter cloacae GT036 survived better than other coliforms in the borehole water after boiling with bacterial count of $3.20 \times$ $10^{1}$. In the wastewaters, at least 4-log reduction was observed in the bacterial counts after 15 minutes of boiling but the counts were still considerably higher than the environmental waters. The survival rate of this study conforms to existing investigations that killing effect against bacteria by boiling is achievable at temperatures above $65^{\circ} \mathrm{C}$ with less than 1 minute per log reduction (24). However, the efficacy of boiling is dependent on clarity of water and contact time (25); thus longer exposure time or preclarification may be required to completely inactivate the coliforms in wastewater due to its high turbidity.

Studies have reported that antibiotic sensitivity of bacteria increases after UV radiation, although some bacteria exhibit increased resistance due to $\mathrm{R}$-factor mediated resistance to UV light $(26,27,28)$. In this study, all the coliforms remained multi-drug resistant after UV exposure for 30 minutes but there was no significant difference in the resistance profiles of the isolates pre and post exposure. The persistence of these MDR enteric bacteria in water and wastewater post-disinfection further affirms these sources as reservoir and transmission routes for resistant pathogens.
Wastewaters provide an environment for potential exchange of antibiotic resistance genes between pathogens, hence the need for effective treatment (29). Incessant discharges of domestic and veterinary effluents into the environment thus presage extensive dissemination of antibiotic resistant pathogens. Also, the increased and intensive use of antibiotics in food animal production in the last decades has greatly influenced antibiotic residue concentrations in their wastewaters, and consequently the threat to public health (30). These results therefore suggest that UV radiation may inactivate coliform growth but may not effectively attenuate antibiotic resistance.

\section{Conclusion:}

This study emphasises the influence of different treatment regimens on coliform survival in wastewaters and environmental waters. Thus, boiling exhibited the highest efficacy with about 5-log reduction in survival rate of the coliforms while the least efficacy was seen in solar irradiation. Also, the effect of the stress by UV radiation did not increase the sensitivity of the coliforms to antibiotics. Consequently, the quality of waters and wastewaters should be duly monitored to prevent the spread of resistant pathogens that could pose great risks to public health.

\section{References:}

1. Hervert, C., Martin, N., Boor, K., and Wiedmann, M. Survival and detection of coliforms, Enterobacteriaceae, and gramnegative bacteria in Greek yogurt. J Dairy Sci. 2017; 100 (2): 950-960.

2. Brown, S, and Jun, S. Complete Genome Sequence of Escherichia coli NCM3722. Genome Announcements 2015; 3 (4): e00879-15.

3. BioProject. Escherichia coli FAP1 (ID 224241) BioProject - NCBI. 2017; https://www.ncbi.nlm.nih.gov/bioproject/22424 1 [Accessed 6 Aug. 2017].

4. Xavier, B., Vervoort, J., Stewardson, A., Adriaenssens, N., Coenen, S., Harbarth, S., Goossens, H., and Malhotra-Kumar S. Complete Geno- me Sequences of Nitrofurantoin-Sensitive and-Resistant Escherichia coli ST540 and ST2747 Strains. Genome Announcements. 2014; 2 (2): e00239-14-e00239-14.

5. Gong, G., Um, Y., Park, T., and Woo, H. Complete genome sequence of Enterobacter cloacae GGT 036: A furfural tolerant soil bacterium. J Biotechnol. 2015; 193: 43-44.

6. UniProt. Shigella sonnei 53G 2017; http://www.uniprot.org/taxonomy/216599 [Accessed 6 Aug. 2017].

7. Centre for Diseases and Control. A Guide to Drinking Water Treatment and Sanitation for Backcountry and Travel. 2017; Available at: https://www.cdc.gov/healthywater/drinking/tra vel/backcountry water treatment.html

[Accessed 6 Aug. 2017]

8. New York Department of Health. Boil Water Response-Information for the Public Health Professional. 2017; https://www.health.ny.gov/environmental/wate r/drinking/boilwater/response_information_publi 
c health professional.html [Accessed 6 Aug. 2017].

9. Caslake, L., Connolly, D., Menon, V., Duncanson, C., Rojas, R., and Tavakoli, J. Disinfection of Conta- minated Water by Using Solar Irradiation. Appl Environ Microbiol. 2004; 70 (2): 1145-1151.

10. Dababneh, F., Walid, D., and Bassim, E. Coliform-Specific Solar Disinfection of treated wastewater. J Environ Studies. 2012; 21 (6): 1577-1581

11. Western Australia Department of Health. WA Health, Government of Western Australia 2017; http://www.health.wa.gov.au/ [Accessed 6 Aug. 2017].

12. Sutton, S. Measurement of cell concentration in suspension by optical density 2006; Retrieved 2015, from The Microbiology Network.

13. Bauer, A. W., Kirby, W. M. M., Sherris, J. C., and Turk, M. Antibiotic susceptibility testing by a stand- ardized single disk method. Am J Clin Pathol 1966; 45: 6-493.

14. Getenga, Z. M., Dorfler, U., Reiner, S, and Sabine, K. Determination of a suitable sterilisation method for soil in isoproturon biodegradation studies. Bulletin of Environmental Contamination and Toxicology. 2004; 72 (2): 415-421

15. Adebisi, O. O., Olaoye, A. J., Senewo, T. V., and Obuekwe, I. S. How long can enteric pathogens survive in polluted environmenta media? African Scientist. 2016; 17 (3): 259267.

16. Adebisi, O. O., Kayode, Y. I., Adeoye, M. I., Afolabi, G. O., and Akinsolu, F. T. Persistence and changes in antibiotic susceptibility patterns of clinical isolates of enteric bacteria in environmental waters and wastewaters. Nig J Pure Appl Sci. 2017; 30 (1): 3014-3029

17. World Health Organization. Water for health: WHO guidelines for drinking water quality 2006; http://www. who.int/watersanitationhealth

18. Akpoveta, O., Okoh, B., and Osakwe, S. Quality Assessment of Borehole Water used in the Vicinities of Benin, Edo State and Agbor, Delta State of Nigeria. Curr Res Chem. 2011; 3 (1): 62-69.

19. Awoyemi, O., Achudume, A., and Okoya, A. The Physicochemical Quality of Groundwater in Relation to Surface Water Pollution in Majidun Area of Ikorodu, Lagos State, Nigeria. Am J Water Res. 2014; 2 (5): 126-133.

20. Palamuleni, L., and Akoth, M. Physico-Chemical and Microbial Analysis of Selected Borehole
Water in Mahikeng, South Africa. Int J Environ Res Publ HIth. 2015; 12 (8): 8619-8630.

21. World Health Organization. Guidelines for drinking water quality. Third edition. 2008; 1 : 3. http://www.who.int/water sanitationhealth

22. Buerger, S., Spoering, A., Gavrish, E., Leslin, C., Ling, L., and Epstein, S. Microbial Scout Hypothesis, Stochastic Exit from Dormancy, and the Nature of Slow Growers. App Environ Microbiol. 2012; 78 (9): 3221-3228.

23. Kell, D., Potgieter, M., and Pretorius E. Individuality, phenotypic differentiation, dormancy and 'persistence' in culturable bacterial systems: commonalities shared by environ- mental, laboratory, and clinical microbiology F1000Research. 2015; 4: 179

24. World Health Organization. 2017; http://www. who.int/water sanitationhealth/dwq /Boiling_water_01_15.pdf [Accessed 6 Aug. 2017].

25. Spinks, A., Dunstan, R., Harrison, T., Coombes, P., and Kuczera, G. Thermal inactivation of water-borne pathogenic and indicator bacteria at sub-boiling temperatures. Water Res 2006; 40 (6): 1326-1332.

26. Tweats, D.J., Thompson, M. J., Pinney, R. J., and Smith, J. T. R factor-mediated resistance to ultra- violet light in strains of Escherichia coli deficient in known repair functions. J Gen Microbiol. 1976; 93 (1): 103-110.

27. Gomez-Couso, H., Fontan-Sainz, M., McGuigan, G., and Ares-Masaz, E. Effect of the radiation intensity, water turbidity and exposure time on the survival of Cryptosporidium during stimulated solar disinfection of drinking water. Acta Trop. 2009; 1 (112): 43-48.

28. Kolappan, A., and Satheesh, S. Efficacy of UV Treatment in Management of Bacteria. J Microbiol. 2011; 119-123.

29. Mechai, A., Debabza, M., Thabet, R., Sedira, H., Fadeleddine, S., and Mechai, A. Occurrence and spread of beta-lactamases-producing Enterobacteriaceae isolated from river receiving treated effluent of wastewater treatment plant. Desal Water Treatment. 2019; 147: 156163. doi: 10.5004/dwt.2019.23763

30. Amador, P., Fernandes, R., Prudêncio, M., Barreto, M., and Duarte, I. Antibiotic resistance in wastewater: Occurrence and fate of Enterobacteriaceae producers of Class $A$ and Class C $\beta$-lactamases. J Environ Sci HIth. 2014; 50 (1): 26-39. 